\title{
Instrução agrícola, saúde, higiene e moralização dos costumes na Cartilha do agricultor
}

Farming instrucution, health, hygiene and moralization of practices in the Farmer's guide Instrucción agrícola, salud, higiene y moralización de las costumbres en la Cartilha do agricultor

\author{
Joaquim Tavares da Conceição \\ Universidade Federal de Sergipe (Brasil) \\ http://orcid.org/0000-0002-8826-8137 \\ http://lattes.cnpq.br/6407061514040419 \\ joaquimcodapufs@gmail.com \\ Aristela Arestides Lima \\ Instituto Federal de Sergipe (Brasil) \\ http://orcid.org/0000-0003-3038-0422 \\ http://lattes.cnpq.br/1443374303005863 \\ aristelar@hotmail.com
}

\section{Resumo}

Este artigo apresenta uma compreensão historiográfica da Cartilha do agricultor, evidenciando aspectos de sua materialidade, circulação e apropriações no ensino agrícola. Quanto ao conteúdo, analisa instruções da agricultura científica e padrões de higienização e moralização dos costumes que a obra almejou incutir entre a população rural. Foram analisadas duas edições da cartilha, organizadas em cinco volumes, publicadas nos anos de 1969 e 1970 pela Secretaria da Agricultura do Estado do Rio Grande do Sul. Produzida com o intuito de atingir um público regional, a obra seguiu diferentes itinerários, alcançando leitores em outras regiões do Brasil. A cartilha pode ser compreendida como um manual de moralização de costumes e de inculcação de padrões higiênicos e, principalmente, como difusora de conhecimentos agronômicos, com o propósito de forjar um agricultor produtivo e moralizado segundo os padrões vigentes.

Palavras-chave: Cartilha do agricultor. Ensino agrícola. Modernização da agricultura. 


\begin{abstract}
This article presents a historiographical comprehension of the Farmer's guide, emphasizing aspects of its materiality, circulation and appropriations in agricultural teaching. Regarding the content, it analyses instructions of the scientific agriculture and standards of hygiene and moralization of the customs that the book intended to instill among the rural population. Two editions of the guide were analysed, organized in 05 volumes, published in the years 1969 and 1970 by the State of Rio Grande do Sul's Agriculture Department . In order to achieve a regional audience, this work had followed different routes, reaching readers in other regions of Brazil. This booklet can be understood as a manual of practices' moralization and also of inculcation of hygienic standards and, mainly, as diffuser of agronomic know-how for the purpose of forging a productive farmer and moralizing according to the current standards.
\end{abstract}

Key-words: Farmer's guide. Agricultural education. Modernization of agriculture.

\title{
Resumen
}

Este artículo presenta una comprensión historiográfica de la Cartilha do agricultor, atendiendo aspectos de su materialidad, circulación y apropiaciones en la enseñanza de la agricultura. En cuanto al contenido, analiza instrucciones de la agricultura científica y patrones de higienización y moralización de las costumbres que la obra anheló infundir entre la población. Se analizaron dos ediciones de la cartilla, organizadas en cinco volúmenes, publicadas en los años 1969 y 1970 por la Secretaría de Agricultura del Estado de Rio Grande do Sul. Producida con el propósito de alcanzar un público regional, la obra ha seguido diferentes trayectorias, alcanzando lectores en otras regiones de Brasil. La cartilla puede entenderse como un manual de moralización de costumbres y de inculcación de conductas higiénicas $\mathrm{y}$, principalmente, como difusora de conocimientos agronómicos con el propósito de forjar un agricultor productivo y moralizado según los patrones vigentes.

Palabras clave: Cartilha do agricultor. Enseñanza agrícola. Modernización de la agricultura. 


\section{Introdução}

Este artigo apresenta uma compreensão historiográfica da Cartilha do agricultor, evidenciando aspectos de sua materialidade, indícios de circulação e apropriações no ensino profissional agrícola federal; analisa ensinamentos morais e higiênicos e instruções da agricultura científica que a obra almejou difundir e incutir entre a população rural. Para a escrita deste artigo, foram analisadas duas edições da cartilha publicadas no ano de 1969 e 1970, produzidas pela Secretaria da Agricultura do Estado do Rio Grande do Sul, cada edição composta de cinco volumes (livros) e, como o próprio título indica, direcionada ao agricultor.

Conquanto tenha utilizado a denominação de "cartilha", a obra apresenta materialidade, direcionamento, funcionalidade e conteúdos diferentes das antigas cartilhas de leitura e/ou voltadas a ensinamentos rudimentares. Portanto, não se aplica à Cartilha do agricultor o sentido tradicional de cartilha como pequeno livro utilizado em processos de alfabetização e/ou práticas de ensino de leitura, o qual se materializava como um conjunto de artifícios facilitadores de decodificação das letras do alfabeto, contendo páginas com pequenos textos, ilustradas com diferentes figuras em cores, e que também se prestavam para a disseminação de conteúdos moralizadores (BOTO, 2004; MACIEL, 2002). Os cinco volumes da Cartilha do agricultor apresentam textos e conteúdos acessíveis a um público adulto alfabetizado, com razoável domínio de leitura e escrita e noções básicas de conteúdos matemáticos. Como enfatizado na obra, em carta dirigida ao agricultor, a cartilha "[...] não é um abecedário, mas valerá por um 'Tratado Elementar' de noções essências à dignificação social do trabalho e da vida rurícola. A 'Cartilha' tem o sentido de Vade-Mécum: vai pela minha mão, que eu te levarei” (CARTILHA DO AGRICULTOR, 1970, v.5, p. 273).

Portanto, a proximidade que a Cartilha do agricultor guarda com antigas cartilhas de leitura - muitas em circulação na segunda metade do século XX, quando a cartilha foi publicada e circulou - fica adstrita aos conteúdos moralizadores enfatizados e ao incentivo que faz para que o agricultor e sua família cultivem o hábito da leitura.

Amigo agricultor: se conheces alguém que não sabe ler, providencie para que ele aprenda, indica para ele uma escola, ou consiga uma pessoa que o queira ensinar. Aquele que não sabe ler é parecido com o cego, que não pode ver. Faze com que tua família descubra o hábito da leitura. Desenvolve em ti, em teus filhos, este hábito. Separa uma prateleira em um armário ou compra um armário simples, e nele vai colocando os teus livros. Será a tua biblioteca. Nela colocará a 'Cartilha', ao lado dos outros livros, teus amigos de todas as horas e momentos (CARTILHA DO AGRICULTOR, 1970, v. 1, p.186).

A compreensão da Cartilha do agricultor estabelecida neste trabalho faz uso de estudos a respeito da produção e circulação de impressos de Roger Chartier (1998, 1999, 2003), buscando entender dispositivos ou estratégias textuais e intenções da autoria/edição e materialidade. A pesquisa igualmente recepciona contribuições de trabalhos sobre a história do ensino agrícola e de aspectos do ruralismo brasileiro (CONCEIÇÃO, 2012, 2015; NASCIMENTO, 2004; MENDONÇA, 1997), como também dialoga com outras interpretações acerca de sentidos da Cartilha do agricultor (KLANOVICZ, 2007).

\section{Materialidade e finalidade da Cartilha do agricultor}

Como ressalta Chartier (1998), os dispositivos presentes em um impresso revelam estratégias textuais e intenções do autor e/ou do editor: 
Contra a representação elaborada pela própria literatura e retomada pela mais quantitativa das histórias do livro - segundo a qual o texto existe em si mesmo, isolado de toda a materialidade - deve-se lembrar que não há texto fora do suporte que o dá a ler (ou ouvir), e sublinhar o fato de que não existe a compreensão de um texto, qualquer que ele seja, que não dependa das formas através das quais ele atinge o seu leitor (p. 17).

Nesse sentido, o suporte da Cartilha do agricultor, edições de 1969 e 1970, apresenta em cada um dos cinco volumes com a dimensão de $18 \mathrm{~cm}$ x $27 \mathrm{~cm}$, impresso em composição mecânica com a utilização de papel comum. A encadernação da edição de 1969 é do tipo brochura, ou seja, miolo costurado na lombada e colado a uma capa mole, confeccionada com papel mais grosso do que as páginas internas; a capa apresenta uma ilustração colorida e que se repete em todos os volumes da edição. A edição de 1970 é encadernada em capa dura e miolo costurado, capa de cor azul em todos os seus volumes e sem ilustração, contendo as indicações do título da obra, volume, temas tratados, órgão promotor, cidade e ano da edição. Alguns aspectos da materialidade podem ser observados nas figuras apresentadas a seguir:

Figura 1. Capa da Cartilha do agricultor (1969). Figura 2. Capa da Cartilha do agricultor (1970).

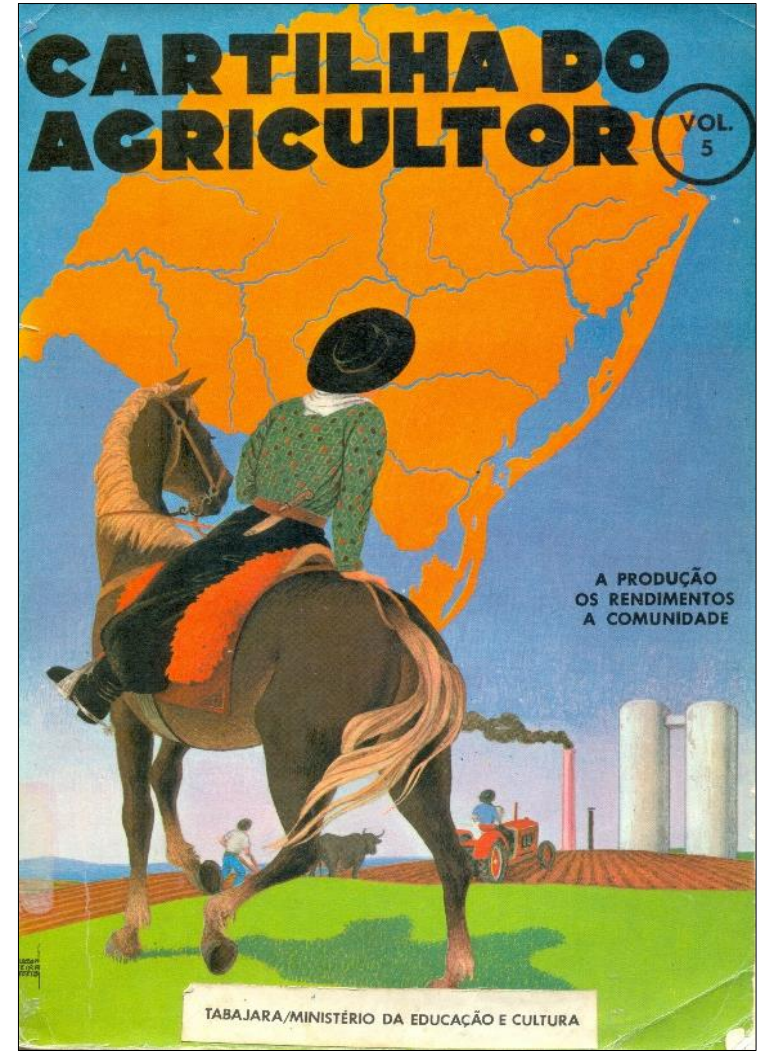

Fonte: Cartilha do agricultor, v. 5, 1969. Acervo da Biblioteca João Ribeiro. Instituto Federal de Sergipe Campus São Cristóvão.

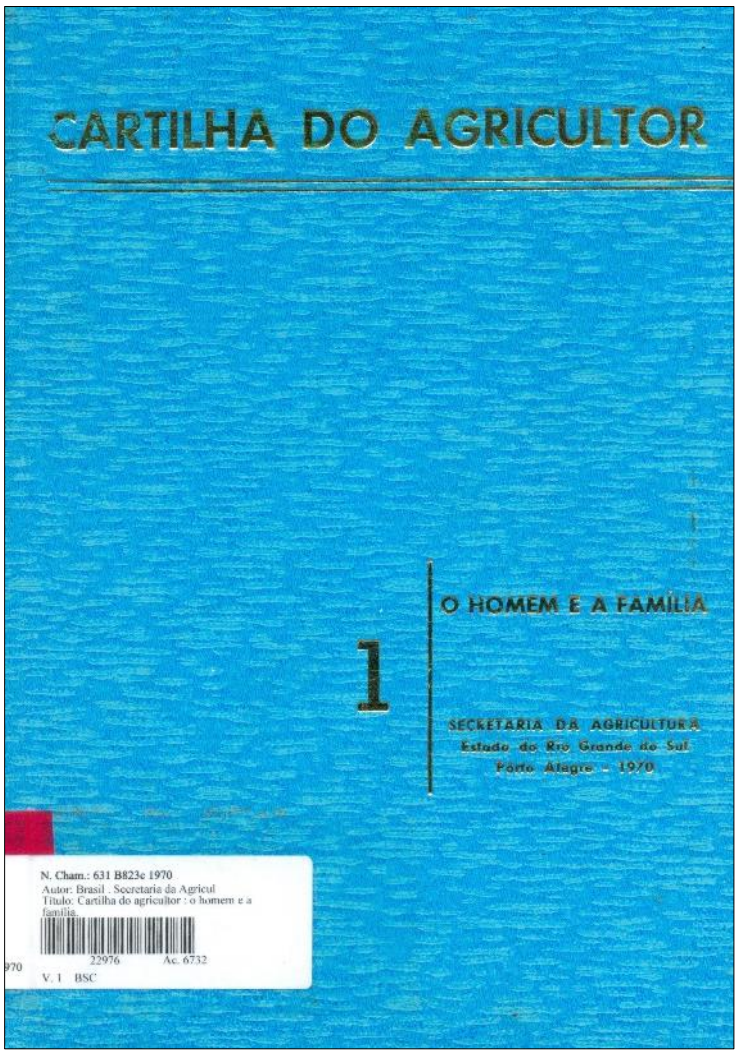

Fonte: Cartilha do agricultor, v. 1 (1970). Acervo da Biblioteca João Ribeiro. Instituto Federal de Sergipe Campus São Cristóvão.

Em ambas as edições consultadas, todos os volumes apresentam como divisões internas: capa, contracapa, folha de rosto, verso da folha de rosto, plano da obra, plano do volume, agradecimento, itens (capítulos) e o índice geral. No volume 1 existe uma apresentação, denominada de "Carta ao agricultor", e no volume 5, uma conclusão com a denominação de "A carta de encerramento". Nas duas edições da cartilha a organização e o conteúdo são 
semelhantes e apresentam páginas com textos, ilustrações com desenhos e fotos em preto e branco. No rodapé de todas as páginas aparece sempre uma máxima e/ou chamada grafada em negrito. A figura em seguida apresenta aspecto interno da cartilha em que podem ser identificadas algumas dessas características.

Figura 3. Aspecto interno da Cartilha do agricultor (1970)

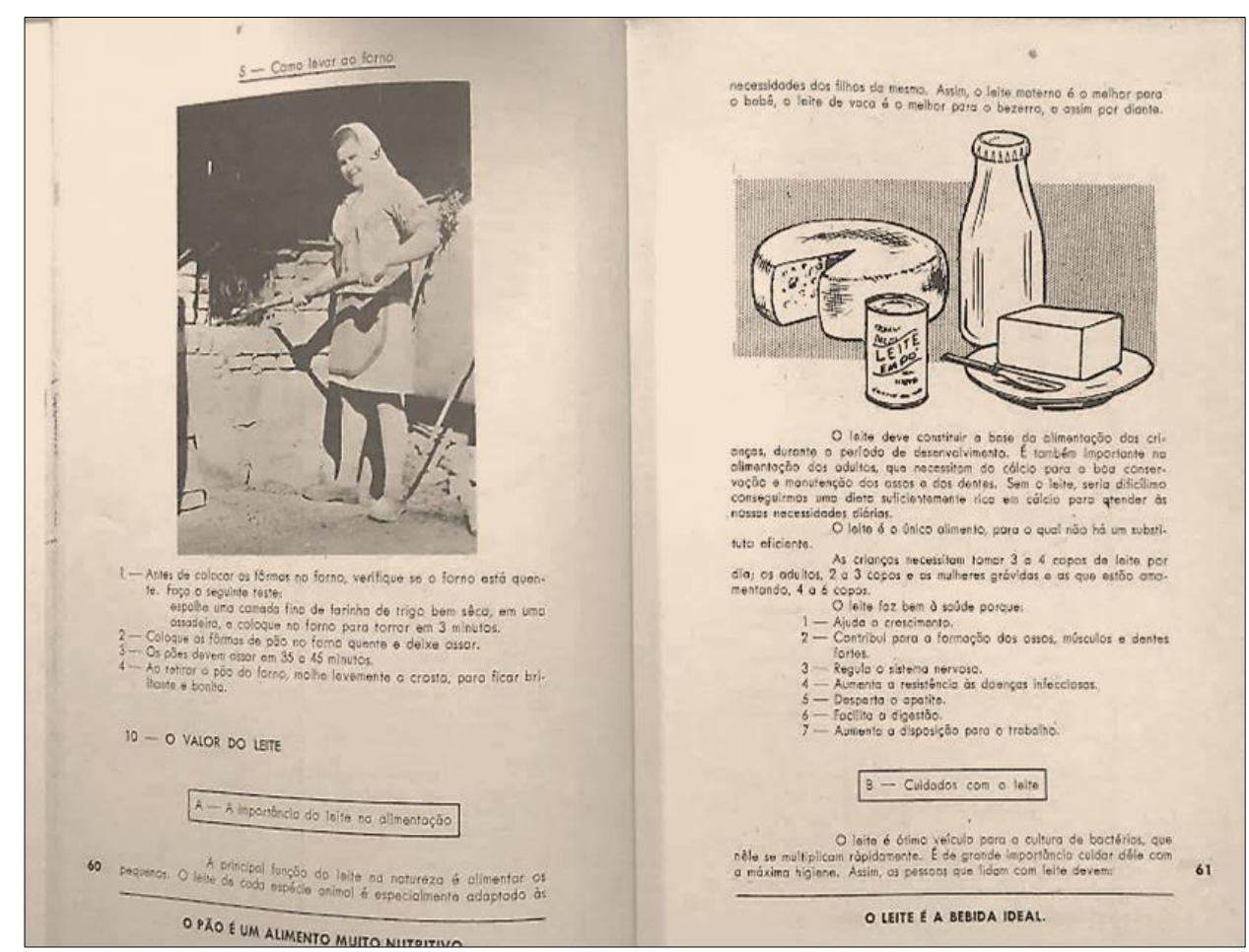

Fonte: Cartilha do agricultor, v. 1, 1970, p. 60.

Produzida pela Secretaria de Agricultura do Estado do Rio Grande do Sul, a Cartilha do agricultor foi editada e publicada pela editora Edições Tabajara ${ }^{1}$, sediada em Porto Alegre. A produção da obra foi coordenada pelos engenheiros agrônomos Oswaldo Baucke e Nilson Gonçalves Maia e contou com a colaboração ${ }^{2}$ de secretarias de Estado do Rio Grande do Sul, órgãos e/ou entidades estaduais e federais, instituições de ensino superior, institutos de pesquisa, escolas técnicas, instituições de fomento e/ou assistência agrícola e a participação de diversos profissionais, sobretudo de engenheiros agrônomos. O impresso não apresenta dados a respeito da tiragem. Quanto à circulação, Klanovicz (2007) informa que a cartilha "[...] foi amplamente distribuída no mundo rural gaúcho, chegando também ao oeste de Santa Catarina" (p. 12).

\footnotetext{
${ }^{1}$ Essa editora produziu no Estado do Rio Grande do Sul livros para o ensino da leitura, entre outros: As férias com vovô (1968), Cartilha do Guri - Método de palavras geradoras (1965). PERES, Eliane. Autoras de obras didáticas e livros para o ensino da leitura produzidos no Rio Grande do Sul: contribuições à história da alfabetização (1950-1970). Educação Unisinos. v. 12, n. 2, maio - agosto, 2008.

${ }^{2}$ Associação Sulina de Crédito e Assistência Rural - Ascar, Banco do Brasil, Instituto Brasileiro de Reforma Agrária - IBRA, Pontifícia Universidade Católica do Rio Grande do Sul - PUCRGS, Secretaria da Agricultura do Rio Grande do Sul, Secretaria de Educação e Cultura do Rio Grande do Sul, Secretaria de Saúde do Rio Grande do Sul, Faculdade de Agronomia e Veterinária da UFRGS, Instituto de Pesquisas e Experimentação Agropecuárias do Sul - IPEAS, Instituto Riograndense do Arroz - IRGA, Instituo Gaúcho de Reforma Agrária - IGRA, Ministério da Agricultura, Banco do Brasil, Comissão Estadual de Silos e Armazéns da UFRGS, Instituto de Estudos e Pesquisas Econômicas - IEPE, Escola Técnica do Comércio, Instituto Nacional do Desenvolvimento Agrário - IBRA (CARTILHA DO AGRICULTOR, 1970, v. 1, 2, 3, 4 e 5).
} 
A obra apresenta textos curtos, diretivos, geralmente em forma de esquema, com exemplos, ilustrações de como fazer e/ou executar determinada atividade, receitas, orientações de higiene rural e preceitos morais, informações técnicas para o meio rural - calendários de plantio e/ou colheita de determinada cultura, dentre outras informações. Nas duas edições, a obra apresenta dez partes distribuídas em cinco livros (volumes), e cada uma delas corresponde a uma temática desenvolvida em divisões denominadas de "itens". O quadro em sequência apresenta o plano dos cinco volumes da Cartilha do agricultor com informações acerca das temáticas e/ou partes abordadas em cada volume e a quantidade de páginas.

Quadro 1. Cartilha do agricultor - Plano da obra (edições de 1969 e 1970)

\begin{tabular}{|c|c|c|c|}
\hline $\mathbf{N}^{\circ}$ & Volume & $\mathrm{N}^{0}$ de páginas & Partes/Temas \\
\hline 01 & $1^{\mathrm{o}}$ & 214 & $\begin{array}{l}1^{\text {a }} \text { Parte }- \text { Apresentação } \\
2^{\text {a }} \text { Parte }- \text { O homem e a família }\end{array}$ \\
\hline 02 & $2^{\circ}$ & 208 & $\begin{array}{l}3^{\text {a }} \text { Parte }- \text { A casa e os haveres } \\
4^{\text {a }} \text { Parte }- \text { A terra }\end{array}$ \\
\hline 03 & $3^{\circ}$ & 635 & $5^{\text {a }}$ Parte - As lavouras e as plantas \\
\hline 04 & $4^{\circ}$ & 416 & $6^{\text {a }}$ Parte - Os animais \\
\hline 05 & $5^{\circ}$ & 286 & $\begin{array}{l}7^{\text {a }} \text { Parte }- \text { A produção } \\
8^{\text {a }} \text { Parte }- \text { Os rendimentos } \\
9^{\text {a }} \text { Parte }- \text { A comunidade } \\
10^{\mathrm{a}} \text { Parte }- \text { Conclusão }\end{array}$ \\
\hline
\end{tabular}

Fonte: Cartilha do agricultor, 1969, 1970, v. 1, 2, 3, 4 e 5.

A respeito da finalidade e dos temas/assuntos tratados na Cartilha do agricultor, Luciano Machado, secretário da agricultura do Rio Grande do Sul, no ano em que a obra foi publicada, dirigia-se aos agricultores, almejados leitores da obra, por meio de uma "carta de apresentação" em que ressaltava a pretensão de que a obra servisse como "roteiro da forma de proceder" para o agricultor:

A Cartilha do agricultor examina, desde a vossa pessoa e a vida dos vossos familiares, assim como as condições da vossa habitação, até a terra e o que ela representa, as lavouras e as plantas, os animais, a produção, os rendimentos e a vossa ação no seio da comunidade.

Em cada um dos cinco volumes da Cartilha ireis encontrar um roteiro da forma de proceder, caso por caso, de modo que vosso trabalho seja produtivo, seguro e efetivamente econômico (CARTILHA DO AGRICULTOR, 1970, v.1, p. 12). 
Figura 4. Cartilha do agricultor (1970)

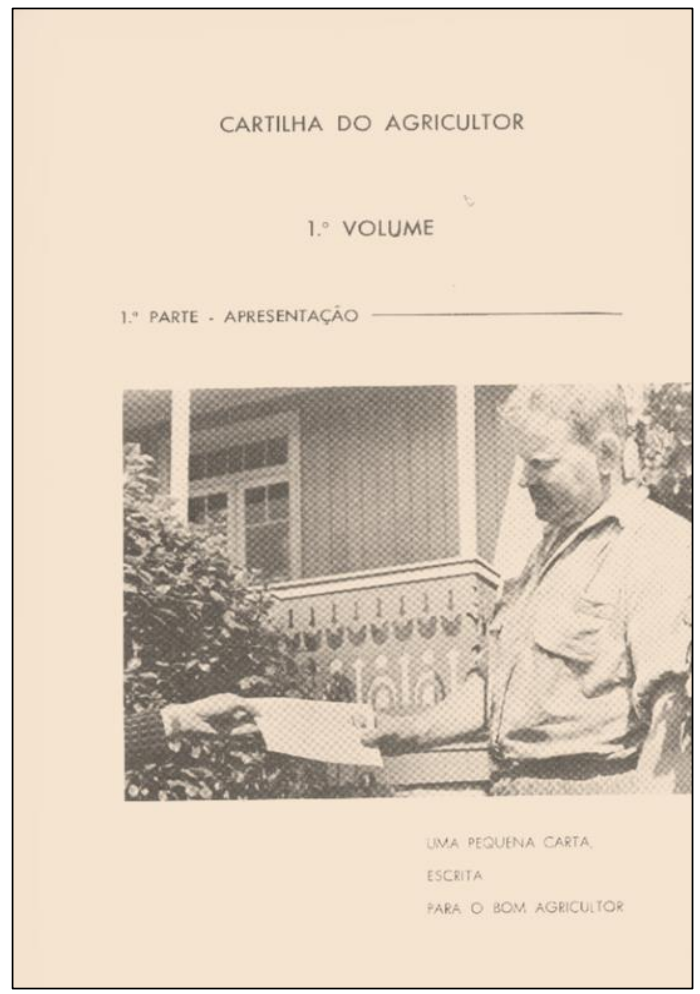

Fonte: Cartilha do agricultor, v. 1, 1970, p. 11.

$\mathrm{Na}$ "Carta de encerramento" da obra, volume 5, novamente são enfatizados o agricultor como o destinatário oficial da obra e o anseio de que a Cartilha servisse como um "livro de cabeceira" para ele e sua família.

A 'Cartilha' deverá ser um livro de 'cabeceira', para manuseio cotidiano pelos pais e filhos, junto ao fogo acolhedor do lar doméstico. Abrindo o caminho do progresso, a 'Cartilha' terá o mérito de valioso legado ao patrimônio do homem que trabalha a terra, para produzir o alimento necessário ao corpo e à paz do espírito (CARTILHA DO AGRICULTOR, 1970, v. 5, p.273).

Logo, a Cartilha do agricultor representou um projeto ambicioso e pretendeu funcionar como um completo "tratado de boas maneiras" ou manual de "bem viver" no campo. Um dispositivo de conformação em que o agricultor se apropriasse dessa obra e a utilizasse como um "bem precioso", um instrumento para o "progresso" da produção agrícola, da saúde humana e animal e para a propagação de comportamentos morais e higiênicos no meio rural. Deste modo, a cartilha preocupou-se em disseminar o que oficialmente era considerado "bons hábitos", combatendo costumes e/ou vivências tradicionais da população rural, identificando-se ao espírito moralizador e diretivo da época.

Igualmente, observa-se a representação do campo como atrasado e seus moradores possuidores de hábitos anti-higiênicos e de vícios a serem corrigidos. Como ressaltado em documentos dos anos de 1970, a educação era vista como solução “[...] para ajudar os agricultores a aprenderem a identificar as causas de seu atraso, capacitando-os, ao mesmo tempo, a solucionarem os respectivos problemas envolvidos" (BRASIL, 1972, p.98). Nesse contexto, a Cartilha do agricultor deveria funcionar como um dispositivo de enquadramento do homem rural, contribuindo para forjar um agricultor produtivo e moralizado segundo o ideário do estado autoritário. Assim, conforme interpreta Klanovicz (2007), a cartilha estabeleceu '[...] uma espécie de 'tipo ideal' do trabalhador e do mundo rural que se opunham 
ao lavrador sem higiene e sem saúde, tradicional, 'arcaico', e que ainda não havia sido atingido pela assistência técnica e pela extensão rural modernas" (p. 5).

Especialmente a respeito dos conhecimentos técnico-científicos divulgados na obra, observa-se a permanência do discurso de modernização da agricultura brasileira por meio da vulgarização da agricultura científica realizada pelos serviços de extensionismo rural. Ou seja, tratava-se da vitalidade e permanência histórica da "[...] fé na ciência como valor máximo capaz de promover a reabilitação agrícola do país" (MENDONÇA, 1997, p. 68), enfatizado pelo campo agronômico desde o início do século XX. A "regeneração" da agricultura brasileira continuava a depender da atuação de técnicos especializados, pois o "saber" do homem do campo não podia dar conta do processo "renovador" que se apresentava destinado a debelar o "atraso" agrícola do país.

\section{Circulação da Cartilha do agricultor no ensino agrícola federal}

Nas primeiras décadas do século XX, intelectuais avaliavam que a melhoria das condições econômicas, morais e mentais da população rural deveria ocorrer por meio da instrução com, por exemplo, a criação de salas para o desenvolvimento das aulas teóricas e de áreas para demonstrações de práticas agrícolas à população rural (TORRES FILHO, 1926). A expansão do ensino agrícola era anunciada como ação importante para o desenvolvimento da agricultura brasileira e para a promoção de mudanças nas práticas culturais do homem do campo. Como comentado anteriormente, no contexto de produção e circulação da Cartilha do agricultor esse discurso de modernização da agricultura brasileira, por meio do uso de novos conhecimentos e técnicas para alavancar a produtividade agrícola e a instrução do agricultor, continuava bastante atuante.

Nos anos de 1970, o Ministério da Educação mantinha uma rede de colégios agrícolas em que se desenvolvia o ensino profissional agrícola por meio do modelo denominado de escola-fazenda ${ }^{3}$. Desde o ano de 1966 fora firmado o convênio entre Ministério da Agricultura ${ }^{4}$, o Conselho de Cooperação Técnica da Aliança para o Progresso (CONTAP) e a United States Agency for International Development ${ }^{5}$ (USAID), cujos objetivos eram a reestruturação do ensino técnico agrícola brasileiro e o desenvolvimento do setor agrícola, por meio da "[...] expansão dos serviços de extensão agrícola, de crédito rural, da produção e utilização de máquinas para agricultura, de produtos químicos, inseticidas, adubos, etc" (ALVES, 1968, p. 90). Os conteúdos disseminados pela Cartilha do agricultor apresentam consonância com essa perspectiva de desenvolvimento da agricultura brasileira pelo constante incentivo à mecanização agrícola, utilização da química agrícola e de tantos outros insumos resultantes de pesquisas agronômicas. Igualmente, o plano de conteúdo da cartilha apresenta similitudes com os conhecimentos projetados nas disciplinas do ensino profissional agrícola constantes da "estrutura curricular do ensino agrícola", publicado pelo Ministério da Educação e Cultura através da Diretoria do Ensino Agrícola, que terminava como disciplinas de "cultura técnica": agricultura, zootecnia, indústrias rurais, mecanização agrícola e economia rural (BRASIL, 1970, 1977).

Contudo, a proximidade da cartilha com o ensino agrícola vai além da similaridade de conteúdos preconizados na obra com diretrizes curriculares dessa modalidade de ensino profissional em voga na época. Embora a obra não tenha sido produzida visando à circulação em nível nacional, tampouco como material para uso nas escolas, acabou sendo adquirida pelo Ministério da Educação

\footnotetext{
${ }^{3}$ Modelo pedagógico de ensino agrícola criado em 1966 e introduzido na rede federal de escolas agrícolas nas décadas seguintes. Tinha como princípio básico o lema “aprender a fazer e fazer para aprender". BRASIL. Ministério da Educação. Sistema Escola Fazenda. Brasília: SENETE, 1990.

${ }^{4}$ No ano de 1967 ocorre a transferência do ensino agrícola e de toda a rede federal dos estabelecimentos desse ramo de ensino do Ministério da Agricultura para a competência do Ministério da Educação. BRASIL. Decreto ${ }^{\circ}$ 60.731, de 19 de maio de 1967. Transfere para o Ministério da Educação e Cultura os órgãos de ensino do Ministério da Agricultura e dá outras providências. SICON (Sistema de Informações do Congresso Nacional), 1967. Disponível em: http://www.senado.gov.br/sicon.

${ }^{5}$ Agência dos Estados Unidos para o Desenvolvimento Internacional.
} 
através da Campanha Nacional de Material de Ensino (CNME) ${ }^{6}$ da Fundação Nacional de Material Escolar (FENAME) e distribuída nos colégios agrícolas federais nos anos 70 do século XX. Por conseguinte, a presença de duas edições completas da Cartilha do agricultor no acervo da Biblioteca João Ribeiro do antigo Colégio Agrícola Benjamin Constant, localizado no povoado Quissamã, município de São Cristóvão, estado de Sergipe, deveu-se à remessa de livros enviados à instituição pela FENAME.

A origem do Colégio Agrícola Benjamin Constant remonta ao ano de 1924 quando surgiu o Patronato Agrícola São Maurício, instituição dedicada à assistência de menores desvalidos e de formação de mão de obra agrícola, fundado pelo então presidente do Estado, Maurício Graccho Cardoso (NERY, 2006). No ano de 1934, o Patronato Agrícola foi federalizado e passou a ser denominado de Aprendizado Agrícola de Sergipe. No período de 1934 a 1967, a instituição esteve vinculada ao Ministério da Agricultura e desenvolveu diversos modelos de ensino agrícola: Aprendizado Agrícola (1934-1947), Escola de Iniciação Agrícola (1946-1952), Escola Agrícola (1952-1957), Escola Agrotécnica (1957-1964), Colégio Agrícola (1964-1979). A partir de 1979 a instituição recebeu a denominação de Escola Agrotécnica Federal de São Cristóvão e, atualmente, é parte integrante do Instituto Federal de Sergipe (IFS), com a denominação de Campus São Cristóvão (CONCEIÇÃO, 2012, 2015; NASCIMENTO, 2004).

Incorporados ao acervo da Biblioteca João Ribeiro, os cinco volumes da Cartilha do agricultor apresentam registros de consulta por estudantes do estabelecimento durante as décadas de 70,80 e 90 do século XX.

Figura 5. Ficha de empréstimo - Cartilha do Agricultor, 1970, v. 5.

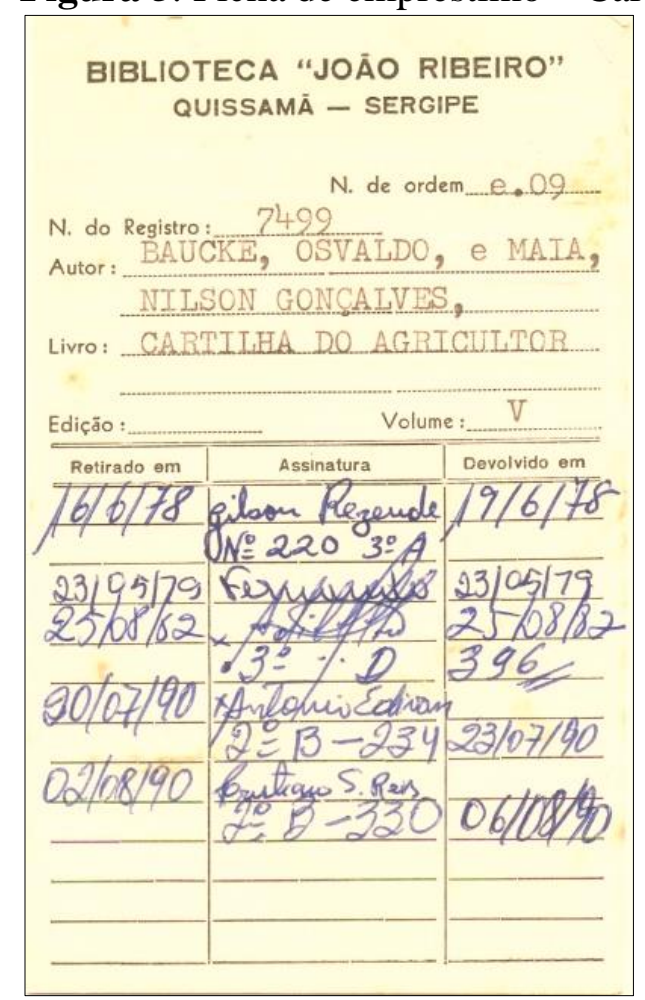

Fonte: Ficha de empréstimo ao leitor. Acervo da Biblioteca João Ribeiro do Colégio Agrícola Benjamim Constant.

\footnotetext{
${ }^{6}$ A CNME foi fundada no ano de 1956 pelo Ministério da Educação. Em 1967 foi transformada em FENAME. Seu propósito era produzir materiais escolares, obras didáticas, e distribuição de materiais de consumo para os estudantes brasileiros. FILGUEIRAS, Juliana Miranda. A produção de materiais didáticos pelo MEC: da Campanha Nacional de Material de Ensino à Fundação Nacional de Material Escolar. Revista Brasileira de História. São Paulo, v. 33, nº 65, p. 313-335, 2013.
} 
Essa aventura da Cartilha do agricultor é ilustrativa de como um material impresso com determinados propósitos educativos e/ou direcionado a determinado público acaba circulando em diferentes espaços e com apropriações diferentes dos propósitos originais. Assim, produzida pelo governo do Rio Grande do Sul, com a finalidade de instruir o agricultor local, a obra viajou pelo Brasil, passou a fazer parte de uma biblioteca localizada em um povoado do município de São Cristóvão, no estado de Sergipe, e foi manuseada por estudantes do ensino profissional agrícola. Como ressalta Roger Chartier, o lugar de produção, o quê e para quem se produziu identificam o ponto de partida, mas não determinam a chegada, porque a "encarnação do texto numa materialidade específica carrega as diferentes interpretações, compreensões e usos de seus diferentes públicos" (CHARTIER, 1999, p.18).

Ainda que a cartilha tenha visado atingir um público regional, enfatizando em parte aspectos específicos de criações animais e plantios tradicionais do estado do Rio Grande do Sul e/ou da região Sul do país, sua circulação em outras regiões pode ser em parte explicada pelas noções gerais a respeito de produção animal e agrícola e, principalmente, pelo plano da obra muito semelhante a conteúdos ensinados em estabelecimentos federais de ensino agrícola instalados em diversos estados e regiões do país. Ou seja, havia consenso no tocante à importância da disseminação entre os agricultores brasileiros de novas técnicas e insumos agrícolas, mecanização agrícola, administração e economia rural, higiene e moralização dos costumes e cooperativismo agrícola, conteúdos presentes na Cartilha do agricultor.

\section{Conhecimentos difundidos na Cartilha do agricultor}

A Cartilha do agricultor intencionou a moralização de costumes, a difusão de conhecimentos técnicos e/ou científicos e a indicação de padrões higiênicos, com o propósito de criar uma nova mentalidade do agricultor. A esse respeito, o secretário da agricultura do Rio Grande do Sul, Luciano Machado, escrevera aos agricultores exaltando o valor da educação para a conquista das inovações produzidas, pois, segundo ele, "[...] os problemas continuarão insolúveis se o agricultor não ler, ouvir, aprender e executar os ensinamentos da técnica agrícola moderna" (CARTILHA DO AGRICULTOR, 1970, v. 1, p.12). Essa perspectiva de modernização da agricultura estava presente na cartilha desde a ilustração que figura na capa da edição de 1969. A ilustração (ver figura 1) dessa edição apresenta em primeiro plano um agricultor montado a cavalo, trajando roupas e indumentárias típicas da cultura gaúcha. Em segundo plano aparecem agricultores lavrando a terra com arado manual e outro usando o trator, e no fundo a presença da agroindústria. Levando em conta os discursos que circulavam na época e o conteúdo disseminado na cartilha, fica evidente a mensagem governamental de que o "progresso" no/do campo só podia ser atingindo quando o homem "rurícola" se apropriasse de conhecimentos técnicos e científicos, da mecanização agrícola, e se habituasse ao uso de novos insumos agrícolas resultante de pesquisas agronômicas.

Por conseguinte, essa "fala técnica" no "mundo rural" consistia na subordinação do campo aos ditames da ciência e da tecnologia agrícola, e seria implementada e vulgarizada pelas ações de extensionismo promovidas pelos órgãos estatais. Esse discurso de tecnificação da agricultura estava presente nos debates ruralistas desde a segunda metade do século XIX, intensificando-se no decorrer do século XX (MENDONÇA, 1997). Como bem analisou Mendonça (1997), a "fala técnica" exigia para o seu sucesso e expansão um grande número de interlocutores e emissários capacitados para acolher, compreender e utilizar prescrições técnicas e científicas da agronomia. Era imperiosa a formação de uma hierarquia da "fala técnica", em que os agrônomos se legitimavam no ponto mais alto da escala hierárquica do saber e, subordinados a eles, em escalas inferiores, os técnicos-médios, trabalhadores do campo capacitados, e agricultores. Todos estes cada vez menos resistentes às mudanças na tarefa de cultivar a terra pelo emprego da moderna técnica agrícola. 
Desse modo, observa-se na cartilha o combate ao "empirismo" como uma permanência da "fala técnica" na agricultura, característica alhures ressaltada por engenheiros agrônomos. Nesse sentido, o agrônomo Lourenço Granato, autor de diversas publicações agronômicas e de ensino agrícola, escrevia em tom de denúncia que o "empirismo" do agricultor brasileiro era uma das causas do atraso da agricultura brasileira:

insistimos no empirismo produzindo a caro preço tudo quanto a technica agrícola nos poderia habilitar a produzir por muito menos. $\mathrm{E}$ tudo isto porque? Porque o empirismo nos envolve nas suas densas trevas. [...] O nosso lavrador é do povo que menos lê e, no seu ramo de agricultor, é o que julga saber mais. [...] Somos um paiz eminentemente agrícola e somos lavradores empíricos. Triste realidade! Enquanto em outros paizes, para os quaes a natureza foi menos prodiga do que para o nosso, se sulca com instrumentos aperfeiçoados o seio da terra e se fertiliza o sólo com materiaes próprios[...]"'(GRANATO, 1918, p. 14).

Além do combate ao "empirismo" ou os saberes e fazeres tradicionais do agricultor brasileiro, a organização e os conteúdos da cartilha lembram que a modernização agrícola do país passava também pela moralização dos costumes e adoção de padrões higiênicos pelo homem do campo. Por isso, como evidenciado nos itens elencados no quadro 2, no volume 1 da obra, com o tema "O homem e a família", são significativos os ensinamentos em torno da higiene e saúde e a inculcação de valores e/ou costumes morais.

Quadro 2. Assuntos abordados na Cartilha do agricultor (1970)

\begin{tabular}{|l|l|}
\hline \multicolumn{2}{|c|}{ Títulos dos itens (v. 1) } \\
\hline 01. A higiene e a saúde - A boa alimentação & 12. O alcoolismo \\
\hline 02. Os cuidados com a futura mãe & 13. O Jogo \\
\hline 03. Os cuidados com o bebê & 14. O valor da família \\
\hline 04. Os cuidados com as crianças & 15. O valor da educação \\
\hline 05. A educação da criança & 16. O valor da leitura \\
\hline 06. Os acidentes e os primeiros socorros & 17. O valor do trabalho \\
\hline 07. Medicamentos de emergência & 18. O valor da poupança ou economia \\
\hline 08. Combate às pragas domésticas & 19. O valor da recreação \\
\hline 09. As vacinas & 20. A saúde do espírito \\
\cline { 1 - 2 } 10. A tuberculose no homem & 21. Direitos e deveres do cidadão \\
\hline 11. Os vermes & \\
\hline
\end{tabular}

Fonte: Cartilha do agricultor, 1970, v. 1.

Difundir conhecimentos acerca da utilização de práticas de higiene, alcançando o corpo do agricultor e de sua família, combatendo parasitas, doenças e prevenindo acidentes, é, portanto, a tônica de conteúdos abordados no volume 1 da Cartilha do agricultor. O banho, o valor da boa alimentação, a higiene corporal da mulher grávida, vacinação, primeiros socorros no caso de acidentes, entre outros, são ensinamentos incutidos com o intuito de preservação da saúde e conformação de costumes (CARTILHA DO AGRICULTOR, 1970, v.1). Para isso, a cartilha utiliza uma linguagem prescritiva e diretiva, indicando valores e comportamentos a serem seguidos pelo agricultor. Assim, é ressaltado o valor da organização da família tradicional, da instrução escolar, do trabalho agrícola, da economia dos rendimentos, da recreação e "saúde do espírito", conforme ilustrado nos seguintes conselhos ou chamativas presentes no volume 1: "A família é a base social da Pátria" (p. 177); "A escola 
é continuação da família" (p. 181); "O hábito da leitura é o mais sadio de todos os hábitos" (p. 184); "Trabalhar é dar segurança e tranquilidade à família" (p. 187); "Mão que economiza é mão que não pede" (p. 191); "O trabalho distrai o espírito e dignifica o homem" (p. 194); "A sadia recreação distrai o espírito" (p. 192).

Em geral, são ensinamentos advindos da moral cristã que se voltam para o combate a vícios - alcoolismo, jogo -, deixando transparecer a visão oficial de um homem que precisava ser salvo da ignorância e precariedade moral pela civilização dos costumes (KLANOVICZ, 2007). O interesse era na gestação de um homem produtivo em um contex to em que o discurso de vocação agrícola do país exigia agricultores instruídos, sadios e moralizados. Daí o combate aos vícios, pois, como alerta a cartilha, a prática de vício incapacita o homem para o trabalho: "O álcool destrói o organismo e tira a capacidade para o trabalho" (CARTILHA DO AGRICULTOR, 1970, v. 1, p. 173).

Figura 6. Ilustração. Combate ao alcoolismo na Cartilha do agricultor.

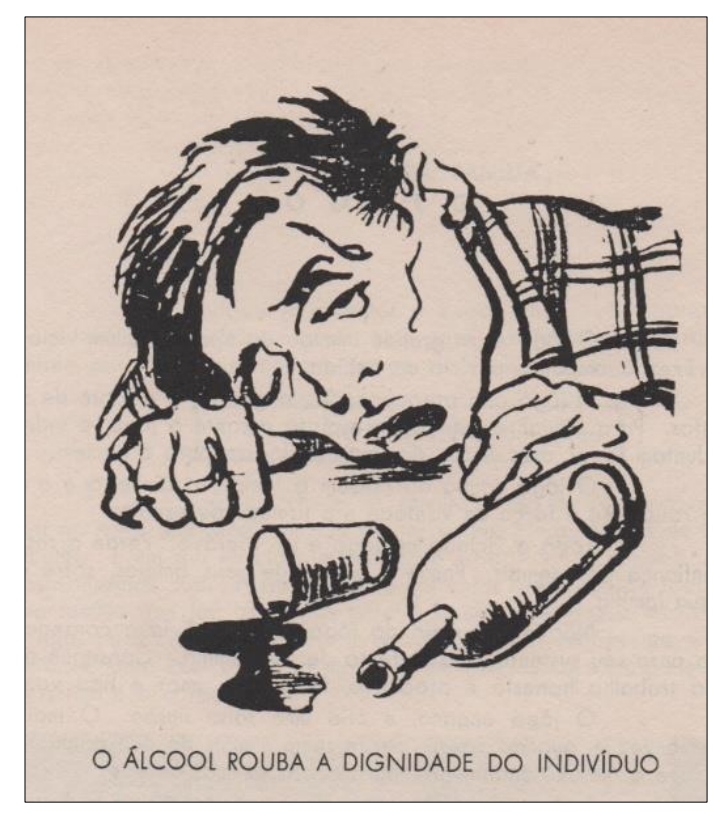

Fonte: Cartilha do agricultor, 1970, v.1, p. 175.

A cartilha foi produzida em um contexto de estado de exceção, ou seja, estava em voga a Ditadura civil-militar (1964-1985). Por isso o seu programa deve ser compreendido dentro da ideia de sociedade e valores que o regime autoritário procurou incutir, especialmente, a educação moral e cívica. Nesse período o governo militar determinava a obrigatoriedade da disciplina Educação Moral e Cívica nas escolas, em todas as modalidades de ensino (CUNHA 2007; BOMENY, 2011). Essa disciplina escolar foi criada no governo militar, ancorada no "culto da obediência à Lei, da fidelidade ao trabalho e da integração na comunidade" (BRASIL, 1969). O estado autoritário também empregou um discurso de dedicação à família, o "culto à pátria", aos seus símbolos e aos grandes vultos da história do Brasil, e a exigência de adesão sem contestação. Estes são valores que a Cartilha do agricultor também se esforçou em valorizar e disseminar.

Deste modo, o conjunto dos conteúdos que compõe a obra revela versáteis estratégias de controle, condicionamento, domínio e inculcação de padrões dominantes. A Cartilha do agricultor foi produzida e circulou durante a vigência do estado autoritário em que os pais, a escola e a sociedade foram convocados ao processo de construção do espírito moralizador e disciplinador, segundo a doutrina da segurança nacional. Nesse contexto, o amor à pátria significava a obediência ao Estado e subordinação aos seus preceitos ideológicos. Outras visões de mundo, além de perigosas, deveriam ser rechaçadas. 
O volume 2 da obra, com o título "A casa e os haveres, a terra", apresenta ensinamentos e instruções a respeito da moradia rural e sua construção higiênica, desde o local, cômodos, instalações e modelos de construções. Outro tema é a "administração do lar", enfatizando os "trabalhos da dona de casa rural" (CARTILHA DO AGRICULTOR, v. 2, p. 50). E segue com ensinamentos de conteúdo diretamente relacionado com o manejo da terra, práticas conservacionistas do solo e das florestas.

Quadro 3. Assuntos abordados na Cartilha do agricultor (1970)

\begin{tabular}{|l|}
\hline \multicolumn{1}{|c|}{ Títulos dos itens (v. 2) } \\
\hline 01. A casa do agricultor \\
\hline 02. Administração do lar \\
\hline 03. Artesanato doméstico rural \\
\hline 04. As principais ferramentas agrícolas \\
\hline 05. A jardinagem \\
\hline 06. O que é o solo? \\
\hline 07. Preparo do solo \\
\hline 08. Plantio \\
\hline 09. Fertilidade \\
\hline 10. A conservação do solo \\
\hline 11. A acidez do solo \\
\hline 12. Os adubos \\
\hline 13. Adubação \\
\hline 14. As florestas \\
\hline
\end{tabular}

Fonte: Cartilha do agricultor, 1970, v. 2.

É interessante perceber que os conhecimentos e/ou instruções apresentados nesse volume a respeito de construções rurais e outras informações técnicas exigem do leitor conhecimentos prévios a respeito de medidas e cumprimentos, formas geométricas, ângulos e graus, entre outros conhecimentos matemáticos. Esta situação também pode ser percebida em assuntos abordados em outros volumes.

O volume 3 é o mais extenso dos cinco volumes da obra. São 635 páginas, o dobro de páginas da maior parte dos volumes da obra, e a abordagem é essencialmente agrícola, relacionada com tipos de culturas agrícolas e informações a respeito do uso das invenções da química agrícola. Assim, as temáticas são "As lavouras e As plantas" com abordagem de assuntos como cuidados e tratos agrícolas, as pragas que atacam diversos tipos de plantas, uso de defensivos agrícolas, emprego de aeronaves na agricultura. O quadro adiante apresenta os itens tratados no volume 3 , no qual pode ser percebido o direcionamento regional, principalmente pela escolha em oferecer instruções ao agricultor a respeito de cultivos agrícolas próprios da região Sul do Brasil e da aviação agrícola adstrita a regiões e/ou segmentos econômicos específicos da agricultura brasileira. 
Quadro 4. Assuntos abordados na Cartilha do agricultor (1970)

\begin{tabular}{|c|c|}
\hline \multicolumn{2}{|c|}{ Títulos dos itens (v. 3) } \\
\hline 01. As sementes & 16. Instalação de um pomar \\
\hline 02. A poda & 17. Plantas de pomar \\
\hline 03. A enxertia & 18. Principais pragas das plantas de pomar \\
\hline 04. As mudas das árvores frutíferas & 19. Principais doenças das plantas de pomar \\
\hline 05. Os inseticidas & $\begin{array}{l}\text { 20. Diversas plantas: arroz, aveia, centeio, } \\
\text { cevada, milho, painço, sorgo, trigo }\end{array}$ \\
\hline 06. Os fungicidas & $\begin{array}{l}\text { 21. Diversas plantas: amendoim, girassol, linho, } \\
\text { mamona, soja, tungue }\end{array}$ \\
\hline 07. Os herbicidas & 22. Diversas plantas: ervilha, feijão-preto, lentilha \\
\hline 08. A inoculação das leguminosas & $\begin{array}{l}\text { 23. Diversas plantas: feijão-miúdo, feijão-de- } \\
\text { porco, tremoço }\end{array}$ \\
\hline 09. As formigas-cortadeiras & $\begin{array}{l}\text { 24. Diversas plantas: alho, cebola, batata- } \\
\text { doce, batatinha, mandioca }\end{array}$ \\
\hline 10. O cupim da terra & 25. Diversas plantas: cana-de-açúcar, fumo, píretro \\
\hline 11. Instalação de uma horta & 26. Parreira, nogueira-pecã, oliveira \\
\hline 12. Plantas de horta & 27. Diversas plantas: abacaxizeiro, bananeira \\
\hline 13. Principais pragas das plantas de horta & $\begin{array}{l}\text { 28. Diversas plantas: acácia-negra, erva- } \\
\text { mate, eucalipto, pinheiro-brasileiro }\end{array}$ \\
\hline 14. Principais doenças de plantas de horta & 29. Aviação agrícola \\
\hline $\begin{array}{l}\text { 15. Gráficos indicativos das épocas de plantio, } \\
\text { transplante e colheita de hortaliças }\end{array}$ & \\
\hline
\end{tabular}

Fonte: Cartilha do agricultor, 1970, v. 3.

"O bom agricultor cuida da sua criação" é a máxima que abre o volume 4, que, com o título "Os animais", aborda as criações animais desde a alimentação até as técnicas de preservação da saúde animal. Nesse volume observa-se o interesse na divulgação e popularização entre os agricultores de conhecimentos científicos relacionadas com a saúde e reprodução animal, como são ilustrativas as informações e instruções sobre vacinação do rebanho e inseminação artificial.

Quadro 5. Assuntos abordados na Cartilha do agricultor (1970)

\begin{tabular}{|c|c|}
\hline \multicolumn{2}{|c|}{ Títulos dos itens (v. 4) } \\
\hline 01. Minerais e nutricão animal & 14. Exploracão de ovinos \\
\hline $\begin{array}{l}\text { 02. Importância das vitaminas e proteínas na } \\
\text { alimentação animal }\end{array}$ & 15. Inseminação artificial em ovinos \\
\hline 03. Estrume e estrumeira & 16. A criação de porcos \\
\hline 04. Sobras, abrigos e aguadas & 17. A criação de cavalos e muares \\
\hline 05. O carrapato $-\mathrm{o}$ banheiro carrapaticida & 18. A criação de cabras \\
\hline 06. Principais plantas tóxicas para os animais & 19. A criação de coelhos \\
\hline 07. Pastagens & 20. A criação de galinhas \\
\hline 08. Tabela de composição das principais forragens & 21. A criação de perus \\
\hline 09. As principais doenças dos animais & 22. A criação de patos e marrecos \\
\hline 10. Vacinas e suas aplicações & 23. A criação de faisões \\
\hline 11. A criação do gado de corte & 24. A criação de gansos \\
\hline 12. A criação do gado leiteiro & 25. Dados gerais de interesse para os \\
\hline 13. Inseminação artificial em bovinos & criadores \\
\hline
\end{tabular}

Fonte: Cartilha do agricultor, 1970, v. 4. 
"A produção", "Os rendimentos" e "A comunidade" são os destaques do volume 5. Na parte "A produção", a ênfase é instruir o agricultor como coletar e preparar amostras e/ou material para exames laboratoriais, a utilização da mecanização agrícola e as formas de conservação e armazenamento da produção, entre outros assuntos. Na parte "Os rendimentos" a cartilha instrui o agricultor a respeito do registro patrimonial e contábil da propriedade rural e da produção, comercialização de produtos, o cooperativismo, assistência agrícola, legislação agrária, e sobre os serviços disponibilizados ao agricultor por meio dos departamentos da Secretaria da Agricultura do Rio Grande do Sul e da Associação Sulina de Crédito e Assistência Rural (ASCAR).

Quadro 6. Assuntos abordados na Cartilha do agricultor (1970)

\begin{tabular}{|l|l|}
\hline \multicolumn{2}{|c|}{ Títulos dos itens (v. 5) } \\
\hline $\begin{array}{l}\text { 01. Como mandar material para exame - 1. } \\
\text { Material entomológico }\end{array}$ & 12. Comercialização dos produtos agrícolas \\
\hline $\begin{array}{l}\text { 02. Como mandar material para exame - 2. } \\
\text { Material fitopatológico }\end{array}$ & 13. O cooperativismo \\
\hline $\begin{array}{l}\text { 03. Como retirar amostras de terra para } \\
\text { análise }\end{array}$ & 14. Assistência ao agricultor \\
\hline 04. Mecanização da lavoura & 15. A parceria agrícola \\
\hline $\begin{array}{l}\text { 05. Conservação e armazenamento da } \\
\text { produção - 1. Silos e armazéns }\end{array}$ & 16. A terra própria \\
\hline $\begin{array}{l}\text { 06. Conservação e armazenamento da } \\
\text { produção - 2. O paiol de tela }\end{array}$ & 17. Arrendamento de terra \\
\hline $\begin{array}{l}\text { 07. Conservação e armazenamento da } \\
\text { produção - 3. A fenação e a silagem }\end{array}$ & 18. Crédito agrícola \\
\hline $\begin{array}{l}\text { 08. Conservação e armazenamento da } \\
\text { produção - 4. Insetos que atacam grãos e } \\
\text { produtos armazenados }\end{array}$ & 19. Legislação agrária \\
\hline 09. Criação de abelhas & $\begin{array}{l}\text { 21. Secretaria da Agricultura do Rio Grande } \\
\text { do Sul }\end{array}$ \\
\hline $\begin{array}{l}\text { 10. Caça e pesca } \\
\text { 22. Associação Sulina de Crédito e Assistência } \\
\text { Rural - ASCAR }\end{array}$ \\
\hline \begin{tabular}{l} 
11. Patrimônio, produção e rendimentos \\
\hline
\end{tabular}
\end{tabular}

Fonte: Cartilha do agricultor, 1970, v. 5.

No volume 5 também transparece o interesse governamental de que os agricultores pudessem conhecer e utilizar inovações agronômicas e veterinárias, a mecanização agrícola, para alcançar maior produtividade nas plantações agrícolas e criações de animais. A popularização desses conhecimentos e técnicas se daria pela presença de órgãos e/ou agências estatais de assistência ao agricultor através de ações de extensão rural e o incentivo ao associativismo rural por meio do incentivo à criação de cooperativas agrícolas. A figura 6 apresenta uma imagem da cartilha que ilustra a visita de técnico da ASCAR - Associação Sulina de Crédito Assistência Rural, ressaltando para o agricultor a importância de serviços de extensão rural agrícola para o "progresso" da agricultura. 
Figura 7. Aspecto de uma visita de técnico da ASCAR ao agricultor

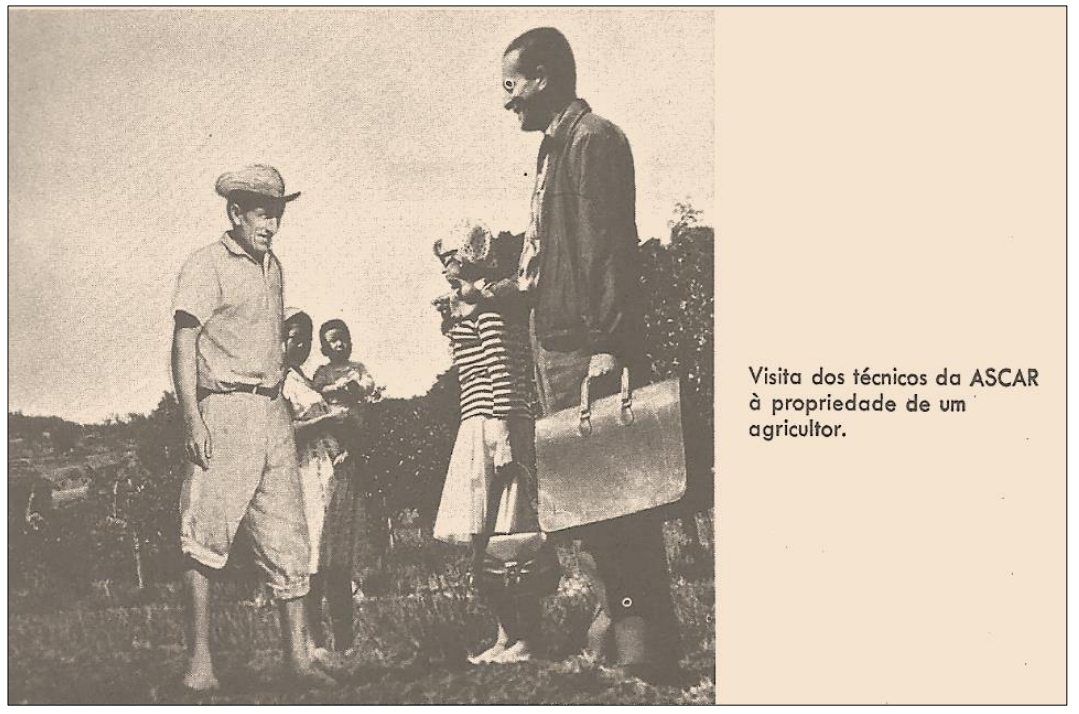

Fonte: Cartilha do agricultor, 1969, v. 5, p. 184.

A presença do técnico no campo demonstra a confiança do governo no avanço da produtividade agrícola pela disseminação da tecnologia entre os produtores rurais. As ações educativas deveriam ocorrer principalmente por meio da ação efetiva dos agrônomos como agentes difusores dos conhecimentos científicos e tecnológicos no meio rural. $\mathrm{O}$ agrônomo extensionista funcionava como intermediário entre a política agrária oficial e o produtor rural. Essa ação também era denominada "agronomia social aplicada", ou extensionismo rural, de forte influência americana (NASCIMENTO, 2004), a qual consistia no serviço oficial de divulgação e propaganda da agricultura técnica e científica no meio rural (TIMMER, 1954). Tal ação educativa dos engenheiros agrônomos, na condição de extencionistas rurais, era vista pelo Ministério da Agricultura como fator importante para difusão entre os produtores rurais dos conhecimentos agronômicos, visando elevar a produtividade agrícola e debelar o "atraso" da agricultura brasileira (TIMMER, 1954, p. 23).

Nessa ação técnica no campo, a visão e/ou descrição do agricultor como "jeca" ou atrasado e que precisava ser salvo de sua ignorância ficava muitas vezes demonstrada.

Em 1956, quando a primeira política de extensão rural e assistência técnica no país foi implantada por meio da Empresa Brasileira de Assistência Técnica e Extensão Rural (Embrater), o agricultor-alvo da extensão passou a ser descrito e tratado como um "jeca" por engenheiros agrônomos e técnicos agrícolas (pelo menos nos primeiros momentos da política de modernização da agricultura). A Embrater era formada pela empresa central do sistema e por congêneres em quase todos os estados brasileiros, tais como a Associação Sulina de Crédito e Assistência Rural (Ascar), do Rio Grande do Sul ou a Associação de Crédito Rural de Santa Catarina (Acaresc), de Santa Catarina. Após sua estruturação, a Embrater e o sistema de Emater locais propugnavam o desafio nacional de modernizar a agricultura e os comportamentos do trabalhador rural, trazendo para si esse papel na forma de "missão." No âmbito de atuação da Ascar e da Acaresc, esse problema nacional encontrava espaço de problematização em nível estadual e periférico e estudar esse problema ali impõe algumas limitações e vantagens (KLANOVICZ, 2007, p. 4). 
O conhecimento sobre a legislação de proteção à fauna e à flora, evitando queimadas, desmatamentos e a caça predatória de animais, são assuntos tratados no volume 5 da Cartilha do agricultor. A fim de persuadir o agricultor a evitar e/ou denunciar a caça ilegal, a cartilha faz uso de ilustrações e mensagens produzidas pela "União Protetora da Natureza". Assim, ao lado de uma fotografia de um passarinho morto por ato de caça ilegal, a cartilha apresenta o seguinte texto:

Os assassinos estão entre nós. O traiçoeiro 'passarinheiro', que enforcou com satânica perversidade o nosso pequeno amigo emplumado, vive no nosso meio. Temos que descobri-lo e encaminhalo à justa punição. Ainda existem muitos dessa espécie de destruidores da Natureza que são uma vergonha para qualquer povo civilizado (CARTILHA DO AGRICULTOR, 1969, v. 5, p.131).

Figura 8. Campanha educativa de proteção à fauna na Cartilha do agricultor (1969)

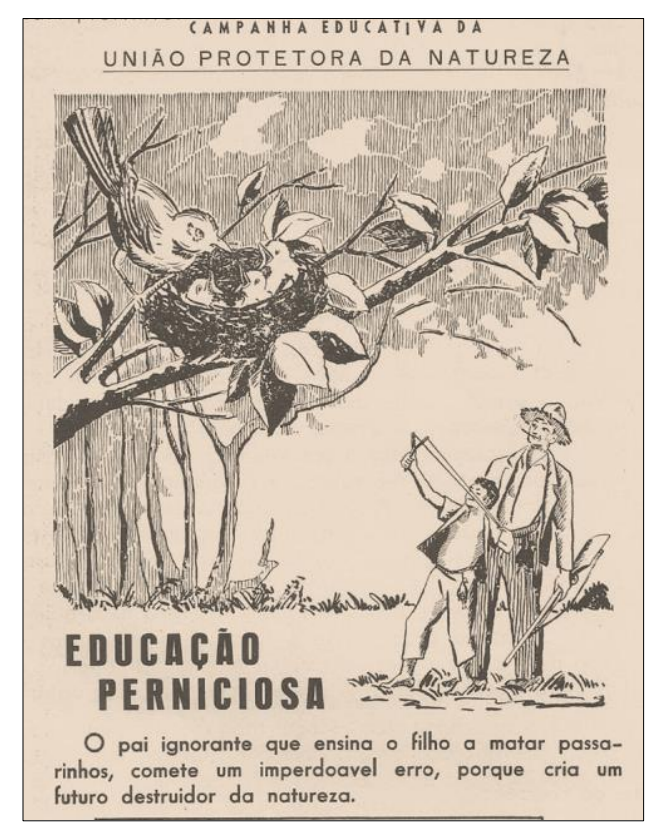

Fonte: Cartilha do agricultor, 1969, v. 5, p. 130.
Figura 9. Campanha educativa de proteção à fauna na Cartilha do agricultor (1969)

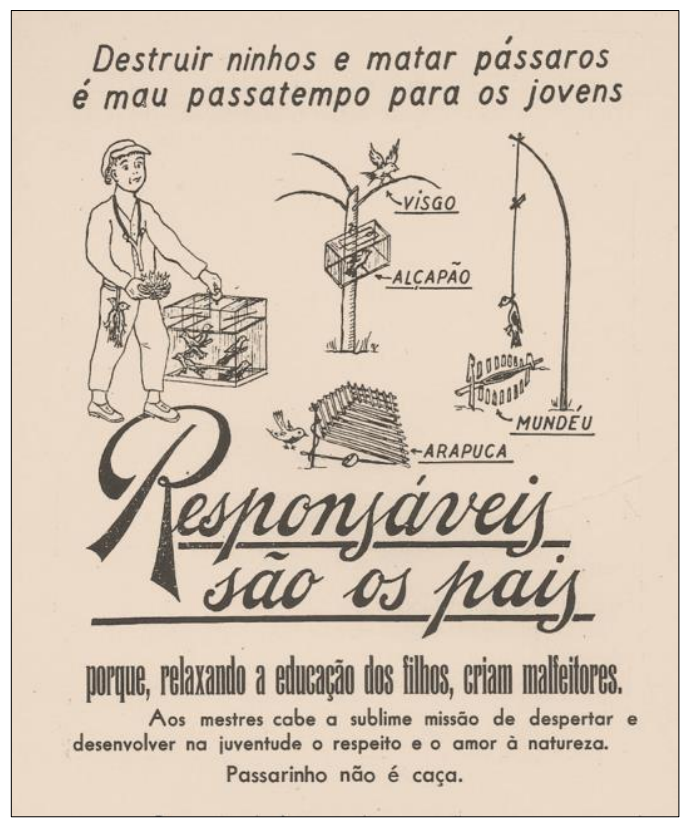

Fonte: Cartilha do agricultor, 1969, v. 5, p. 133.

A necessidade de inserção das novas técnicas e máquinas circula em toda a cartilha. A utilização da mecanização agrícola é destacada como capaz de promover benefícios e melhorias relacionados à diminuição dos custos e aumento da produtividade agrícola. O trator, por exemplo, é apresentado como uma das máquinas mais importantes da mecanização da agricultura, pois apresenta como vantagens: trabalha com alta carga, não tem a influência do tempo, usa a tração em amplos espaços, requer pequeno espaço para abrigo, entre outras.

Os diferentes cenários habilmente envolventes apresentados nos cinco volumes da Cartilha do agricultor são constantemente reforçados pelas máximas em destaque em todas as páginas dos cinco volumes da obra. Em cada página, uma máxima; em cada máxima um incentivo, uma instrução, uma recomendação, um aprendizado, um princípio educativo dirigido ao homem do campo e/ou à sua família e à comunidade rural. 
Quadro 7: Máximas, conselhos e/ou ensinamentos apresentados na Cartilha do agricultor (1970)

\begin{tabular}{|c|c|}
\hline Volume & Máximas \\
\hline \multirow{3}{*}{$\begin{array}{l}\text { v. 1: O homem e a } \\
\text { família }\end{array}$} & A boa saúde confere ao homem disposição para o trabalho (p. 23) \\
\hline & $\begin{array}{l}\text { A leitura é a riqueza do espírito. A "cartilha” é a mais rica de todas as } \\
\text { leituras (p.71) }\end{array}$ \\
\hline & $\begin{array}{l}\text { O conhecimento e a instrução aumentam a capacidade para o trabalho } \\
\text { (p. 177) }\end{array}$ \\
\hline \multirow{3}{*}{$\begin{array}{c}\text { v. 2: A casa e os } \\
\text { haveres } \\
\text { A terra }\end{array}$} & A casa deve ser construída em lugar seco e higiênico (p. 13) \\
\hline & A saúde e a resistência da dona-de-casa são insubstituíveis (p. 51) \\
\hline & Para uma correta adubação, recorra sempre à orientação técnica (p. 193) \\
\hline \multirow{3}{*}{$\begin{array}{l}\text { v. 3: As lavouras e } \\
\text { As plantas }\end{array}$} & Não se alimente enquanto estiver trabalhando com inseticidas (p. 40) \\
\hline & O segredo para o êxito do pomar está na boa qualidade das mudas (p. 284) \\
\hline & O emprego do avião "agrícola" é vantajoso e compensador (p. 616) \\
\hline \multirow[t]{3}{*}{ v. 4: Os animais } & $\begin{array}{l}\text { Um campo livre de plantas tóxicas significa menos problemas e maior } \\
\text { rendimento da criação (p. 59) }\end{array}$ \\
\hline & $\begin{array}{l}\text { Para vacinar com segurança contra a febre aftosa, siga cuidadosamente } \\
\text { as recomendações da "cartilha"! (p. 141) }\end{array}$ \\
\hline & A inseminação artificial é um poderoso meio de melhoria do gado (p. 191) \\
\hline \multirow{3}{*}{$\begin{array}{l}\text { v. 5: A produção } \\
\text { Os rendimentos, A } \\
\text { Comunidade }\end{array}$} & $\begin{array}{l}\text { As máquinas agrícolas multiplicam a capacidade de trabalho do } \\
\text { homem (p. 24) }\end{array}$ \\
\hline & $\begin{array}{l}\text { Os silos e armazéns guardam a abundância de hoje para a escassez de } \\
\text { amanhã (p. 47) }\end{array}$ \\
\hline & A ““'Cartilha do agricultor”” ajuda ampara, ensina e instrui! (p. 192) \\
\hline
\end{tabular}

Fonte: Cartilha do agricultor, v.1, 2, 3, 4, 5 (1970).

A cartilha, através de suas máximas, ressalta a importância de que o agricultor conheça e faça uso de técnicas agrícolas modernas. O "desafio americano" fora lançado; as novas técnicas agrícolas seriam a alternativa para vencer as dificuldades encontradas na agricultura rio-grandense, conforme defendeu o secretário de agricultura. Era necessário produzir mais em menos tempo. A cartilha incentiva a compra de máquinas; orienta o uso de aparelhagem adequada ao estoque de grande produção; informa que as máquinas multiplicam a capacidade de trabalho. Ela também apresenta as condições para o financiamento das técnicas modernas de trabalho: o crédito agrícola. "Com o crédito, poderá pôr em prática tudo quanto a 'cartilha' aconselha" (CARTILHA DO AGRICULTOR, v. 5, 1969, p. 203).

\section{Considerações finais}

A Cartilha do agricultor empreende um discurso que representava a agricultura brasileira como atrasada e indicava como solução a vulgarização e utilização de conhecimentos técnicos e científicos, insumos, maquinário e tecnologia para a modernização e aumento da produtividade agrícola. Contudo, o discurso de uniformização da população do campo empregado na cartilha não leva em conta que nem todos os agricultores estavam em condições econômicas de utilizar as "modernidades" apresentadas. Assim, muitas vezes a mensagem de "modernização da agricultura" fica adstrita a médios e grandes proprietários rurais e muito distante do agricultor familiar, sem recursos para se apropriar dos avanços científicos e tecnológicos propalados pela cartilha. Para esses, o discurso segue o ideário de moralização dos costumes e imposição de padrões higiênicos. 
A linguagem amigável, instrutiva e aconselhadora norteia a mensagem da Cartilha e pode ser resumida nos seguintes princípios: a terra como uma dádiva de Deus, o trabalho agrícola como valor que dignifica o homem e sua família, a instrução que conduz o agricultor à prosperidade e à exaltação da vida no campo.

Por fim, a obra em geral evidencia um contexto em que programas estatais direcionados ao meio rural desqualificavam os saberes tradicionais do agricultor e julgavam poder ensiná-lo como produzir e viver melhor. Por conseguinte, a Cartilha do agricultor deve ser compreendida como impresso produzido também para o controle e conformação moral do indivíduo, neste caso em particular, do homem do campo.

\section{Referências}

ALVES, Márcio Moreira. Beabá dos MEC-USAID. Rio de Janeiro: Gernasa, 1968.

BOMENY, Helena Maria Bousquet. Moral, bons costumes e limites à participação cívica. Desigualdade \& Diversidade - Revista de Ciências Sociais da PUC-Rio, nº 9, p. 181-192, ago/dez, 2011.

BOTO, Carlota. Aprender a ler entre cartilhas: civilidade, civilização e civismo pelas lentes do livro didático. Educação e Pesquisa. São Paulo, v.30, n.3, p. 493-511, set./dez, 2004. https://doi.org/10.1590/S1517-97022004000300009

CHARTIER, Roger. A aventura do Livro: do leitor ao navegador. São Paulo: UNESP, 1999.

CHARTIER, Roger. A ordem dos livros: leitores, autores e bibliotecas na Europa entre os séculos XIV e XVIII. 2 ed. Brasília: Editora da UnB, 1998.

CHARTIER, Roger. Formas e sentido. Cultura escrita: entre distinção e apropriação. Campinas/SP: Mercado de Letras; ALB, 2003.

CONCEIÇÃO, Joaquim Tavares da. A pedagogia de internar. História do internato no Ensino Agrícola Federal (1934-1967). 2007. São Cristóvão: Editora UFS, 2012.

CONCEICAO, Joaquim Tavares da. Perfil dos alunos internos no ensino profissional agrícola federal mantido pelo Ministério da Agricultura em Sergipe (1934-1967). Rev. Bras. Estud. Pedagog., Brasília, v.96, n.244, p.596-615, set./dez, 2015. http://dx.doi.org/10.1590/S2176-6681/346413576.

CUNHA, Luiz Antônio. Sintonia oscilante: religião, moral e civismo no Brasil - 1931-1997. Cadernos de Pesquisa, v.37, n.131, p.285-302, maio/ago 2007. https://doi.org/10.1590/S0100$\underline{15742007000200004}$

FILGUEIRAS, Juliana Miranda. "A produção de materiais didáticos pelo MEC: da Campanha Nacional de Material de Ensino à Fundação Nacional de Material Escolar" Revista Brasileira de História. São Paulo, v.33, n.65, p.313-335, 2013. https://doi.org/10.1590/S0102$\underline{01882013000100013}$

KLANOVICZ, Jó. O Brasil no mundo rural doente: A construção do agricultor na literatura em dois momentos da história brasileira (1914 e 1970). Luso-Brazilian Review. University of Wisconsin Press, v.44, n.1, pp.45-60, 2007. https://doi.org/10.1353/lbr.2007.0028

MACIEL, Francisca Isabel Pereira. As cartilhas e a história da alfabetização no Brasil: alguns apontamentos. História da Educação. ASPHE/FaE/UFPel, Pelotas, v. 6, n. 11, p. 147-168, jan./jun., 2002.

MENDONÇA, Sônia Regina de. O ruralismo brasileiro (1888 -1931). São Paulo: HUCITEC, 1997. 
NASCIMENTO, Jorge Carvalho do. Memórias do aprendizado. 80 anos de ensino agrícola em Sergipe. Maceió: Edições Catavento, 2004.

NERY, Marco Arlindo Amorim Melo. A regeneração da infância pobre sergipana no início do século XX: o Patronato Agrícola de Sergipe e suas práticas educativas. São Cristóvão. Dissertação de Mestrado. Programa de Pós-Graduação em Educação da Universidade Federal de Sergipe. UFS. 2006.

PERES, Eliane. Autoras de obras didáticas e livros para o ensino da leitura produzidos no Rio Grande do Sul: contribuições à história da alfabetização (1950-1970). Educação Unisinos. v.12, n.2, mai./ago., 2008.

\section{Fontes}

BRASIL. Decreto ${ }^{\circ}$ 60.731, de 19 de maio de 1967. Transfere para o Ministério da Educação e Cultura os órgãos de ensino do Ministério da Agricultura e dá outras providências. SICON (Sistema de Informações do Congresso Nacional), 1967. Disponível em: 〈http://www.senado.gov.br/sicon>.

BRASIL. Ministério da Educação e Cultura. Acordos, contratos e convênios. MEC: Oficina Gráfica da Universidade Federal do Rio de Janeiro, 1967.

BRASIL. Decreto-Lei nº ${ }^{\circ}$ 869, 12 de setembro de 1969. Dispõe sobre a inclusão da Educação Moral e Cívica como disciplina obrigatória, nas escolas de todos os graus e modalidades, dos sistemas de ensino no País, e dá outras providências. Disponível em: http://www6.senado.gov.br/legislacao/ListaPublicacoes.action?id=195811. Acesso em: 30.04.2018.

BRASIL. Ministério da Educação e Cultura. Departamento de Ensino Médio. Habilitação Básica em Agropecuária. Fundamentos, currículo, metodologia e avaliação. Brasília: MEC, 1977.

BRASIL. Ministério da Educação e Cultura. Diretoria do Ensino Agrícola. Estrutura Curricular do Ensino Agrícola. Brasília, 1970.

BRASIL. Ministério da Educação e Cultura. Colégio Agrícola Benjamin Constant. Cartão de controle de retirada de livros da Biblioteca João Ribeiro (Cartilha do agricultor, v. 5), São Cristóvão, 1978.

BRASIL. Ministério da Educação. Sistema Escola Fazenda. Brasília: SENETE, 1990.

GRANATO, Lourenço. Ensino Agrícola. São Paulo: B. Mendes \& C.,1918.

Secretaria da Agricultura do Rio Grande do Sul. Cartilha do agricultor. Porto Alegre: Edições Tabajara, 1969 (volumes 1, 2, 3, 4 e 5).

Secretaria da Agricultura do Rio Grande do Sul. Cartilha do agricultor. Porto Alegre: Edições Tabajara, 1970 (volumes 1, 2, 3, 4 e 5).

TIMMER, Willy Johanan. Planejamento do trabalho em extensão agrícola. Rio de Janeiro, Ministério da Agricultura - Serviço de Informação Agrícola, 1954.

TORRES FILHO, Arthur. O ensino agrícola no Brasil. Rio de Janeiro, 1926. 